\title{
A APLICAÇÃO DOS TRATADOS E A DOUTRINA DO CONTROLE DE CONVENCIONALIDADE: BASES JURÍDICAS E EFETIVAÇÃO
}

\section{THE APPLICATION OF TREATIES AND THE DOCTRINE OF CONVENTIONALITY CONTROL: LEGAL BASES AND EFFECTIVENESS}

\author{
Guilherme Vitor de Gonzaga Camilo \\ Mestrando em Direito Internacional pela Pontifícia Universidade Católica de Minas \\ Gerais (Bolsista Capes). Especialista em Direito Internacional pelo Centro de Direito \\ Internacional. E-mail: vitorgvc@ hotmail.com
}

Recebido em: 15/06/2016

Aprovado em: 02/02/2017

Doi: $10.5585 / \mathrm{rdb} . v 17 \mathrm{i} 7.428$

RESUMO: O presente trabalho tem como objetivo apresentar o entendimento acerca da aplicação dos tratados, utilizando para este fim a doutrina do Controle de Convencionalidade, destacando seu papel enquanto instrumento de fortalecimento e efetivação do Direito Internacional e dos Direitos Humanos. Assim, demonstra-se como esta ferramenta foi desenvolvida em meio ao Sistema Interamericano de Direitos Humanos e como tem sido sua aplicação tanto pela Corte Interamericana de Direitos Humanos quanto pelas cortes nacionais. Para isso realiza-se a cobertura histórica sobre a aplicação nacional dos tratados pelas cortes domésticas, apontando como o Supremo Tribunal Federal tem se posicionado sobre o status dos tratados ratificados pelo Brasil e analisando assim a possibilidade de um controle das normas internas pelos diplomas internacionais ratificados pelo Estado, tendo em vista as inovações trazidas pelo novo Código de Processo Civil. Posteriormente, passa-se à construção do Controle de Convencionalidade, com a abordagem do posicionamento da Corte Interamericana de Direitos Humanos acerca de sua aplicação, e a aplicação desta doutrina pelo judiciário brasileiro.

Palavras-Chave: Direitos Humanos; Direito Internacional; Controle de Convencionalidade.

\begin{abstract}
This study aims to present the understanding of the application of treaties, using for this purpose the doctrine of Conventionality Control, highlighting its role as an instrument for strengthening and enforcement of International Law and Human Rights. Thus, it is demonstrated how this tool was developed in the midst of the Inter-American Human Rights System and how it has been implemented by both the Inter-American Court of Human Rights and the national courts. It carries out to historical coverage on the national implementation of treaties by domestic courts, demonstrating how the Supreme Court of Brazil has positioned itself on the status of treaties ratified by the government, and thus analyzing the possibility of control of internal rules for international diplomas ratified by the State, considering the innovations introduced by the new Civil Procedure Code. Later, it moves on to the construction of Conventionality Control with the approach of the Inter-American Court of Human Rights about its application, and the application of this doctrine by the Brazilian judiciary
\end{abstract}

Key-Words: Human Rights; International Law; Conventionality Control 
SUMÁRIO: Introdução. 1. Aplicação dos Tratados no Brasil 2. A construção do Controle de Convencionalidade. 3. A aplicação do Controle de Convencionalidade pelos juízes nacionais 4. Conclusão. Referências Bibliográficas.

\section{INTRODUÇÃO}

O Direito, como afirma a doutrina, é muito mais amplo do que o conjunto de normas que se edita em âmbito nacional. Neste contexto, torna-se necessário analisar a aplicação das fontes de Direito Internacional pela Ordem Jurídica Interna. Entende-se como fontes de Direito Internacional, “[...] os documentos e pronunciamentos de que emanam direitos e deveres das pessoas internacionais configurando os modos formais de constatação do direito internacional."1

O elenco de fontes do Direito Internacional pode ser depreendido do Estatuto da Corte Internacional de Justiça que prescreve em seu artigo 38:

\section{Artigo 38}

1. A Corte, cuja função seja decidir conforme o direito internacional as controvérsias que sejam submetidas, deverá aplicar;

2. as convenções internacionais, sejam gerais ou particulares, que estabeleçam regras expressamente reconhecidas pelos Estados litigantes;

3. o costume internacional como prova de uma prática geralmente aceita como direito;

4. os princípios gerais do direito reconhecidos pelas nações civilizadas;

5. as decisões judiciais e as doutrinas dos publicitários de maior competência das diversas nações, como meio auxiliar para a determinação das regras de direito, sem prejuízo do disposto no Artigo 59.

6. A presente disposição não restringe a faculdade da Corte para decidir um litígio ex aequo et bono, se convier às partes. ${ }^{2}$

Por sua crescente importância no Direito Internacional, será abordado neste trabalho a relevância da aplicação dos tratados na ordem jurídica interna através do que se denomina Controle de Convencionalidade.

Os tratados são conceituados pela Convenção de Viena sobre o Direito dos Tratados como sendo “(...) acordo internacional concluído por escrito entre Estados e regido pelo Direito Internacional, quer conste de um instrumento único, quer de dois ou mais instrumentos conexos, qualquer que seja sua denominação específica."3

Considerando-se a relevância que o Direito Internacional possui atualmente, as disposições da Corte Interamericana de Direitos Humanos e a Convenção de Viena sobre Direito dos Tratados, não se pode mais compreender o Direito Estrangeiro e o Direito Nacional como duas ordens jurídicas que apenas se tocam, pois este entendimento não condiz com a realidade atualmente vivenciada. Desta forma, deve ser assegurada a sua implementação no Estado Brasileiro. Conforme Paulo Borba Casella:

Não mais se pode invocar a dicotomia entre as duas ordens, que levou a alguns "enganos" e "desvios de rumo" cometidos no passado. Doravante, superados.

\footnotetext{
${ }^{1}$ ACCIOLY, Hildebrando; CASELLA, Paulo Borba; SILVA, G. E. do Nascimento. Manual de Direito Internacional Público, 20 ed. São Paulo: Saraiva, 2011, p. 146.

${ }^{2}$ ORGANIZAÇÃO DAS NAÇÕES UNIDAS. Estatuto da Corte Internacional de Justiça. 1945. Disponível em: <http://www.direitoshumanos.usp.br/index.php/Corte-Internacional-de-Justi\%C3\%A7a/estatuto-da-corteinternacional-de-justica.html>. Último acesso: 04 de abril de 2016.

${ }^{3}$ ORGANIZAÇÃ̃ DAS NAÇÕES UNIDAS. Convenção de Viena sobre o Direito dos Tratados. Viena, 23 maio 1969.
} 
Aceito o princípio, resta assegurar a sua implementação, de modo que se passe a aplicar como tal na jurisprudência, e na administração do estado brasileiro, soberano e independente, mas integrado ao mundo e neste inserto, com todas as consequências daí decorrentes, e que não mais podem ser ignoradas, ou tratadas como emanação da boa vontade nacional, em relação ao exterior ${ }^{4}$.

Neste contexto surge o Controle de Convencionalidade. O Controle de Convencionalidade é um conceito difundido pela Corte Interamericana de Direitos Humanos que reflete o respeito dos Estados signatários da Convenção Americana sobre Direitos Humanos ao prever que as obrigações assumidas internacionalmente pelos países devem ser cumpridas, independentemente de seu ordenamento interno, e que os diplomas convencionais devem servir como filtro à aplicação da lei interna. Isso significa que uma norma interna pode deixar de ser aplicada para que o texto da Convenção Americana de Direitos Humanos (CADH) ou de outros tratados de Direitos Humanos integrantes do Sistema Interamericano sejam contemplados.

\section{A APLICAÇÃO DOS TRATADOS NO BRASIL}

Para se compreender o Controle de Convencionalidade é necessário, inicialmente, entender sobre a aplicação dos tratados em nossa ordem jurídica, haja vista que o citado mecanismo baseia-se no cumprimento de obrigações estabelecidas em tratados junto ao Sistema Interamericano de Direitos Humanos.

O ponto inicial de análise quanto à aplicação dos tratados no ordenamento nacional refere-se ao status concedido internamente à estes diplomas.

O Supremo Tribunal Federal manteve por muito tempo o entendimento de que todos os tratados, independente da matéria sobre a qual versavam, eram considerados como direito ordinário.

Sobre a hierarquia dos tratados comuns no ordenamento brasileiro, o precedente de maior destaque anterior à Constituição Federal de 1988 é o Recurso Extraordinário 80.004 de $1977^{5}$ em que foi definida hierarquia equivalente à lei ordinária, seja em relação aos tratados sobre assuntos gerais ou de Direitos Humanos. O referido processo tratou sobre a aplicação da Lei Uniforme de Genebra sobre letras de câmbio e notas promissórias e segundo a Corte, embora o diploma internacional tenha aplicabilidade no direito interno brasileiro, não se sobrepõe às leis editadas no país.

Assim, a resolução de conflitos entre os tratados e as normas de origem interna era realizada pelo critério cronológico ou de especialidade. Exemplo disso é o caso de prisão civil do depositário infiel, proibida pela Convenção Americana sobre Direitos Humanos, mas que o Supremo Tribunal Federal decidiu como subordinada ao texto constitucional brasileiro vez que seu artigo $5^{\circ}$, inciso LXVII ${ }^{6}$ permite a prisão do depositário infiel. Neste caso, o Habeas Corpus $72131^{7}$, o Supremo comparou a Constituição Brasileira com a Constituição Argentina, afirmando

\footnotetext{
${ }^{4}$ ACCIOLY, Hildebrando; CASELlA, Paulo Borba; SILVA, G. E. do Nascimento. Op. Cit, p. 27.

5 BRASIL. Supremo Tribunal Federal. Recurso Extraordinário n. 80.004-SE. Relator: Ministro Xavier de Albuquerque, Plenário, Brasília, DF, DJ, 1 de jun. de 1977 . Disponível em: < http://redir.stf.jus.br/paginadorpub/paginador.jsp?docTP=AC\&docID=175365>. Último acesso: 30 agosto 2016.

${ }^{6}$ Artigo 5º inciso LXVII: não haverá prisão civil por dívida, salvo a do responsável pelo inadimplemento voluntário e inescusável de obrigação alimentícia e a do depositário infiel; BRASIL. Constituição da República Federativa do Brasil de 1988. Brasília, DF, 1988.

${ }^{7}$ BRASIL. Supremo Tribunal de Federal. Habeas Corpus 72131-RJ. Relator: Ministro Marco Aurélio, Plenário, Brasília, DF, DJ 23 nov..1995.
} 
que, caso fosse interesse do legislador, teria diferenciado expressamente o status dos Tratados de Direitos Humanos 8 .

Como forma de conciliar o posicionamento do STF com a visão doutrinária que apontava a constitucionalidade dos tratados de Direitos Humanos, o então Ministro Sepúlveda Pertence sustentou, no Recurso em Habeas Corpus 79785-RJ, processo em que se analisava o direito ao duplo grau de jurisdição, garantido pela $\mathrm{CADH}$, frente ao foro privilegiado garantido aos juízes no ordenamento brasileiro, que

[...] aceitar a outorga de força supra-legal às convenções de direitos humanos, de modo a dar aplicação direta às suas normas - até se necessário, contra a lei ordinária - sempre que, sem ferir a Constituição, a complementem, especificando ou ampliando os direitos e garantias dela constantes. ${ }^{9}$

A posição sustentada pelo Ministro somente obteve êxito com a edição da Emenda Constitucional 45/2004. A Emenda 45 condicionou a hierarquia constitucional dos tratados de Direitos Humanos ao rito de aprovação das emendas constitucionais, criando dois tipos de tratados de Direitos Humanos, os aprovados com o quórum de emenda e os aprovados pelo quórum de lei ordinária, e não mencionou o tratamento que seria dado aos tratados anteriores.

$\mathrm{O}$ status dos tratados de direitos humanos ainda foi alterado diante da decisão proferida pelo STF no Recurso Extraordinário $466.343^{10}$ em 2008 na qual se discutiu a legitimidade da prisão civil do depositário infiel em face do Pacto Internacional dos Direitos Civis e Políticos e da Convenção Americana sobre Direitos humanos (Pacto de São José da Costa Rica). Neste recurso foram consideradas duas posições que elevam o Direito Internacional dos Direitos Humanos à posição superior, dando-lhe posição de direito que permite o controle de legitimidade da lei ordinária. A posição majoritária foi a defendida pelo ministro Gilmar Mendes que conferiu o status de supralegalidade aos tratados de Direitos Humanos, ao contrário da posição defendida pelo ministro Celso de Mello que os considerava como sendo de estatura constitucional.

A Constituição Federal já demonstrava sua escolha pela superioridade dos tratados de Direitos Humanos mesmo antes da EC 45/2004 através de seu artigo $5^{\circ}$, $\S 2^{\circ}$ que preleciona: " $\S$ $2^{0}$ - Os direitos e garantias expressos nesta Constituição não excluem outros decorrentes do regime e dos princípios por ela adotados, ou dos tratados internacionais em que a República Federativa do Brasil seja parte. ${ }^{11}$ " Os $\S \S 3^{\circ}$ e $4^{\circ}$ do referido artigo, incluídos com a EC 45 , também demonstram esta predileção:

$\S 3^{\circ}$ Os tratados e convenções internacionais sobre direitos humanos que forem aprovados, em cada Casa do Congresso Nacional, em dois turnos, por três quintos dos votos dos respectivos membros, serão equivalentes às emendas constitucionais.

$\S 4^{\circ} \mathrm{O}$ Brasil se submete à jurisdição de Tribunal Penal Internacional a cuja criação tenha manifestado adesão. ${ }^{12}$

\footnotetext{
${ }^{8}$ RAMOS, André de Carvalho. Pluralidade das ordens jurídicas: a relação do direito brasileiro com o direito internacional.Curitiba: Juruá, 2012, p.48.

${ }^{9}$ BRASIL. Supremo Tribunal de Federal. Recurso em Habeas Corpus 79785-RJ. Relator: Ministro Sepúlveda Pertence, Plenário, Brasília, DF, DJ 19 set..2003.

${ }^{10}$ BRASIL. Supremo Tribunal de Federal. Recurso Extraordinário 466343-1 SP. Relator: Ministro César Peluso, Plenário, Brasília, DF, DJ 03 dez. 2008. Disponível em: < http://redir.stf.jus.br/paginadorpub/paginador.jsp?docTP=AC\&docID=595444> Último acesso: 30 agosto 2016.

${ }^{11}$ BRASIL. Constituição da República Federativa do Brasil de 1988. Brasília, DF, 1988.

${ }^{12}$ Ibidem.
} 
Desta forma também entendeu o Ministro Gilmar Mendes:

Ressalte-se, nesse sentido, que há disposições da Constituição de 1988 que remetem o intérprete para realidades normativas relativamente diferenciadas em face da concepção tradicional do direito internacional público.

Refiro-me, especificamente, a quatro disposições que sinalizam para uma maior abertura constitucional ao direito internacional e, na visão de alguns, ao direito supranacional. A primeira cláusula consta do parágrafo único do art. $4^{\circ}$, que estabelece que a "República Federativa do Brasil buscará a integração econômica, política, social e cultural dos povos da América Latina, visando à formação de uma comunidade latino-americana de nações".

Em comentário a este artigo, o saudoso Professor Celso Bastos ensinava que tal dispositivo constitucional representa uma clara opção do constituinte pela integração do Brasil em organismos supranacionais.

A segunda cláusula é aquela constante do $\S 2^{\circ}$ do art. $5^{\circ}$, ao estabelecer que os direitos e garantias expressos na Constituição brasileira "não excluem outros decorrentes do regime e dos princípios por ela adotados, ou dos tratados internacionais em que a República Federativa do Brasil seja parte".

A terceira e quarta cláusulas foram acrescentadas pela Emenda Constitucional $\mathrm{n}^{\circ}$ 45, de 08.12.2004, constantes dos $\S \S 3^{\circ}$ e $4^{\circ}$ do art. $5^{\circ}$, que rezam, respectivamente, que "os tratados e convenções internacionais sobre direitos humanos que forem aprovados, em cada Casa do Congresso Nacional, em dois turnos, por três quintos dos votos dos respectivos membros, serão equivalentes às emendas constitucionais", e "o Brasil se submete à jurisdição de Tribunal Penal Internacional a cuja criação tenha manifestado adesão. ${ }^{13}$

Como afirma o Ministro, a predileção do legislador constitucional pelos Direitos Humanos é uma tendência mundial, já, àquele tempo, sendo observada também em outros países do continente americano como o Paraguai, Argentina e Uruguai, sendo esta forma de dar maior efetividade aos Direitos Humanos e aproximar o Direito Constitucional do Direito Internacional.

A tese vencedora no referido recurso foi conforme o voto do Ministro Gilmar Mendes, garantindo a estatura supralegal aos tratados de Direitos Humanos aprovados fora das regras do $\$ 3^{\circ}$, haja vista que a CF não teria garantido o status de emenda constitucional a estes tratados ao prever as disposições do $\S 2^{\circ}$, mas ao mesmo tempo teria concedido especial tratamento.

Assim, a posição atual do Supremo garante a existência de tratados ratificados pelo Brasil com três status diferentes: tratados de Direitos Humanos aprovados com o quórum do artigo $5^{\circ}$, parágrafo $3^{\circ}$ tem status de emenda constitucional, enquanto os tratados de Direitos Humanos não aprovados com o referido quórum tem status supralegal, ou seja, abaixo do status de norma constitucional e acima do status de lei ordinária; os tratados que não versam sobre Direitos Humanos tem status de norma ordinária.

Visando esclarecer o status dos tratados de Direitos Humanos aprovados anteriormente à EC 45/2004, foi desenvolvida pela doutrina brasileira teoria que apontava serem todos materialmente constitucionais, bem como aqueles aprovados após a referida emenda, com base no artigo $5^{\circ}, \S 2^{\circ}$ da CF. Os tratados que seguissem o rito de aprovação do artigo $5^{\circ}$, $\S 3^{\circ}$, seriam além de materialmente, também formalmente constitucionais. Desta forma, somente os tratados formalmente constitucionais não estariam sujeitos à denúncia, haja vista serem cláusulas pétreas $^{14}$.

\footnotetext{
${ }^{13}$ BRASIL. Supremo Tribunal de Federal. Recurso Extraordinário 466343-1 SP. Relator: Ministro César Peluso, Voto do Ministro Gilmar Mendes, Brasília, DF, DJ 03 dez. 2008. Disponível em: < http://redir.stf.jus.br/paginadorpub/paginador.jsp?docTP=AC\&docID=595444> Último acesso: 30 agosto 2016.

${ }^{14}$ RAMOS, André de Carvalho. Op. Cit. p.50.

Revista de Direito Brasileira | São Paulo, SP | v. 17 | n. 7 | p. 18 - 39 | Mai./Ago. 2017
} 
Com a consideração de status constitucional aos tratados de Direitos Humanos, seguindo o rito estabelecido pela Emenda Constitucional 45/2004, surge a possibilidade de se realizar o Controle de Convencionalidade das normas de direito interno pelas cortes nacionais baseado nas próprias normas do ordenamento nacional ${ }^{15}$. Atualmente, somente a Convenção Internacional sobre os Direitos das Pessoas com Deficiência e seu Protocolo Facultativo possuem status de emenda constitucional $^{16}$.

A adoção da Convenção de Viena sobre o Direito dos Tratados pelo Brasil também representa uma nova base para a aplicação nacional do Controle de Convencionalidade. Esta Convenção, em especial seu artigo $27^{17}$, garante a aplicação do Direito Internacional na ordem jurídica interna, contexto no qual se insere o Controle de Convencionalidade. Assim já se manifestou a Corte Interamericana de Direitos Humanos sobre as disposições da convenção:

Como já salientou esta Corte e conforme dispõe o artigo 27 da Convenção de Viena sobre o Direito dos Tratados de 1969, os Estados não podem, por razões de ordem interna, descumprir obrigações internacionais. As obrigações convencionais dos Estados Parte vinculam todos seus poderes e órgãos, os quais devem garantir o cumprimento das disposições convencionais e seus efeitos próprios (effet utile) no plano de seu direito interno. ${ }^{18}$

Conforme Paulo Macedo, as disposições do artigo 27 obrigam o Estado a garantir a aplicação dos tratados pelos órgãos de direito interno ${ }^{19}$, isto porque os países devem cumprir as disposições assumidas através dos tratados com base na boa-fé e pacta sunt servanda. Assim, a CVDT também serve como justificativa para se considerar os tratados como aspecto de validade das normas internas.

Um avanço recente na aplicação do Direito Internacional pelo ordenamento interno se deu com a entrada em vigor do Novo Código de Processo Civil (Lei 13.105/15). O referido diploma dispõe em seu artigo $13^{20}$ sobre a possibilidade de regulamentação da jurisdição processual civil pelos tratados, convenções e acordos internacionais em que o Brasil seja parte. As disposições do referido artigo reforçam a base jurídica do Controle de Convencionalidade em nosso ordenamento ${ }^{21}$, no entanto, tendo em vista que as disposições do CPC já estão submetidas aos diplomas de Direitos Humanos por terem estes o status de norma supralegal ou de emenda constitucional, esta abertura ao Direito Internacional prevista pelo Código pode significar o

\footnotetext{
${ }^{15}$ In like manner 'the constitutionalization of human rights treaties from below' hás actually occurred in Latin America, in which these instruments are incorporated into domestic legal orders with the constitutional rank. As a result, the incorporated international standards function as the parameteror block for the constitutional review of national acts. NEGISHI, Yota. The Pro Homine Principle's role in regulating the relationship between Conventionality Control and Constitutionality Control. Max Plank Institute for Comparative Public Law and International Law (MPIL) Research Paper Series, n.13, 2016, p. 6. Disponível em: < http://papers.ssrn.com/sol3/papers.cfm?abstract id=2791008 >. Último acesso: 30 agosto 2016.

${ }^{16}$ BRASIL.Decreto $n^{\circ}$ 6.949, de 25 de agosto de 2009. Promulga a Convenção Internacional sobre os Direitos das Pessoas com Deficiência e seu Protocolo Facultativo, assinados em Nova York, em 30 de março de 2007. Brasília,DF, 26 agosto 2009.

17 ORGANIZAÇÃO DAS NAÇÕES UNIDAS. Convenção de Viena sobre o Direito dos Tratados. Viena, 23 maio 1969.

${ }^{18}$ CORTE INTERAMERICANA DE DIREITOS HUMANOS. Sentença Caso Gomes Lund e Outros ("Guerrilha do Araguaia") vs. Brasil. 24 novembro 2010.

${ }^{19}$ MACEDO, Paulo. Comentários ao artigo 27. In SALIBA, Aziz Tuffi (org.). Direito dos tratados: comentários à Convenção de Viena sobre o direito dos tratados (1969). Belo Horizonte: Arraes Editores, 2011, p. 191.

${ }^{20}$ Art. 13. A jurisdição civil será regida pelas normas processuais brasileiras, ressalvadas as disposições específicas previstas em tratados, convenções ou acordos internacionais de que o Brasil seja parte. BRASIL. Código de Processo Civil.2015.Brasília, DF, 2015.

${ }^{21}$ MARINONI, Luiz Guilherme et al.Novo Código de Processo Civil Comentado. São Paulo: Revista dos Tribunais, 2015, p. 112.
} 
reconhecimento da subordinação do Direito Processual Civil aos tratados internacionais comuns ${ }^{22}$ e por consequência o exercício de um Controle de Convencionalidade baseado na supralegalidade destes diplomas, como já previa Mazzuoli:

A compatibilização das normas infraconstitucionais com os tratados internacionais comuns faz-se por meio do chamado controle de supralegalidade. Não se trata de controle de convencionalidade pelo fato de se reservar esta última expressão à compatibilidade vertical que devem ter as normas de direito interno com os tratados de direitos humanos, que têm índole e nível constitucionais. No caso dos tratados internacionais comuns, estão eles abaixo da Constituição, mas acima das leis internas. Assim, eles passam a servir de paradigma de supralegalidade das normas domésticas, as quais também serão inválidas se violarem suas disposições ${ }^{23}$.

Este posicionamento do novo código se coaduna com as diposições dos artigos 26 e $27^{24}$ da Convenção de Viena de 1969, garantindo que o Brasil respeite a ordem jurídica internacional, cumprindo seus deveres internacionais de boa-fé, conforme o Pacta Sunt Servanda.

\section{A CONSTRUÇÃO DO CONTROLE DE CONVENCIONALIDADE}

Segundo Bernardo Fernandes, o Controle de Convencionalidade é uma forma de compatibilizar as normas de direito interno e os tratados de direitos humanos ratificados pelo governo e em vigor no país. Controle de validade das normas nacionais que tem como parâmetro os tratados de direitos humanos ${ }^{25}$. Este instrumento serviria justamente o mecanismo de implementação do Direito Internacional na ordem jurídica interna, um grande desafio do Direito Internacional para o século XXI. ${ }^{26}$

A compatibilidade do ordenamento jurídico passa a ser não somente conforme a Constituição, mas ganha um novo parâmetro de adequação, quais sejam as normas de direitos humanos adotadas em âmbito internacional, sendo esta nova forma de se realizar o controle vertical das normas jurídicas. Assim também se posiciona Luiz Guilherme Marinoni:

Vale dizer que a legislação infraconstitucional, para produzir efeitos, não deve apenas estar em consonância com a Constituição Federal, mas também com os tratados de direitos humanos. Nesta perspectiva, existem dois parâmetros de

\footnotetext{
${ }^{22}$ CARVAlHO, Alexander Perazo Nunes de. Convencionalização do direito civil: a aplicação dos tratados e convenções internacionais no âmbito das relações privadas. Revista de Direito Internacional, v. 12, n. 2, 2015, p. 351. Disponível em: < http://www.publicacoesacademicas.uniceub.br/index.php/rdi/article/view/3756/pdf >. Último acesso: 30 agosto 2016.

${ }^{23}$ MAZZUOLI, Valerio de Oliveira. Teoria Geral do Controle de Convencionalidade no Direito Brasileiro. In In MARINONI, Luiz Guilherme; MAZZUOLI, Valerio de Oliveira (Org.). Controle de Convencionalidade: um panorama latino-americano: Brasil, Argentina, Chile, México, Peru, Uruguai. Brasília, DF: Gazeta Jurídica, 2013, p.47-48.

${ }_{24}$ Article 26. "PACTA SUNT SERVANDA" Every treaty in force is binding upon the parties to it and must be performed by them in good faith. Article 27. INTERNAL LAW AND OBSERVANCE OF TREATIES A party may not invoke the provisions of its internal law as justification for its failure to perform a treaty. This rule is without prejudice to article 46. ORGANIZAÇÃO DAS NAÇÕES UNIDAS. Convenção de Viena sobre o Direito dos Tratados. Viena, 23 maio $1969 . \quad$ Disponível em: < https://treaties.un.org/doc/publication/unts/volume\%201155/volume-1155-i-18232-english.pdf>. Último acesso: 30 agosto 2016.

${ }_{25}^{25}$ FERNANDES, Bernardo Gonçalves. Curso de Direito Constitucional, 6 ed. Salvador: Juspodium, 2014, p. 1227.

${ }^{26}$ ACCIOLY, Hildebrando; CASELLA, Paulo Borba; SILVA, G. E. do Nascimento. Op. Cit, p. 125

Revista de Direito Brasileira | São Paulo, SP | v. 17 | n. 7 | p. 18 - 39 | Mai./Ago. 2017
} 
controle e dois programas de validação do direito ordinário. Além da Constituição, o direito supralegal está a condicionar e a controlar a validade da lei.

Isto significa que a lei, nesta dimensão, está submetida a novos limites materiais, postos nos direitos humanos albergados nos tratados internacionais, o que revela que o Estado contemporâneo - que se relaciona, em recíproca colaboração, com outros Estados constitucionais inseridos numa comunidade -, tem capacidade de controlar a legitimidade da lei em face dos direitos humanos tutelados no país e na comunidade latino-americana. ${ }^{27}$

Embora a origem deste controle seja fruto de divergências, a doutrina sustenta que teve origem no sistema francês e data do início da década de 1970 através da Decisão n ${ }^{\circ} 74-54$ DC $^{28}$, de janeiro de 1975, em que o Conselho Constitucional Francês, tendo em vista o status de norma supralegal garantido pela Constituição Francesa em seu artigo $55^{29}$, se declarou incompetente para analisar a convencionalidade preventiva das leis, pelo fato de não se tratar de um controle de constitucionalidade propriamente dito ${ }^{30}$.

No plano interamericano, o Controle de Convencionalidade baseia-se, principalmente nas disposições da $\mathrm{CADH}$, notadamente os artigos 1 e $2^{31}$ que determinam o dever de respeito e garantia dos Direitos Humanos pelos Estados, inclusive adotando as medidas legislativas necessárias, o artigo $29^{32}$ que determina as normas de interpretação da Convenção e os artigos 26 e 27 da Convenção de Viena sobre o Direito dos Tratados ${ }^{33}$ que preveem o Pacta Sunt Servanda,

\footnotetext{
${ }^{27}$ MARINONI, Luiz Guilherme; MITIDIERO, Daniel; SARLET, Ingo Wolfgang. Curso de Direito Constitucional. São Paulo: Editora Revista dos Tribunais, 2012, p. 1187.

${ }^{28}$ FRANÇA. Conselho Constitucional Francês. Decision 74-54 DC, Voluntary Interruption of Pregnancy Act. Decisão de 15 jan. 1975. Disponível em: < http://www.conseil-constitutionnel.fr/conseilconstitutionnel/root/bank/download/7454DCa7454dc.pdf >. Último acesso: 30 agosto 2016.

${ }^{29}$ Artigo 55\%: Os tratados ou acordos regularmente ratificados ou aprovados têm, a partir da sua publicação, autoridade superior à das leis, sujeito, para cada acordo ou tratado, à sua aplicação pela outra parte. FRANÇA. Constituição da Quinta República de 1958. Disponível em: <http://www.conseil-constitutionnel.fr/conseilconstitutionnel/root/bank_mm/portugais/constitution_portugais.pdf >. Último acesso: 30 agosto 2016.

${ }^{30}$ MAZZUOLI, Valerio de Oliveira. O controle jurisdicional da convencionalidade das leis, 3. ed. ver., atual. e ampl. São Paulo: Editora Revista dos Tribunais, 2013, p.88.

31 Artigo 1. Obrigação de respeitar os direitos: 1.Os Estados Partes nesta Convenção comprometem-se a respeitar os direitos e liberdades nela reconhecidos e a garantir seu livre e pleno exercício a toda pessoa que esteja sujeita à sua jurisdição, sem discriminação alguma por motivo de raça, cor, sexo, idioma, religião, opiniões políticas ou de qualquer outra natureza, origem nacional ou social, posição econômica, nascimento ou qualquer outra condição social. 2. Para os efeitos desta Convenção, pessoa é todo ser humano.

Artigo 2. Dever de adotar disposições de direito interno: Se o exercício dos direitos e liberdades mencionados no artigo 1 ainda não estiver garantido por disposições legislativas ou de outra natureza, os Estados Partes comprometem-se a adotar, de acordo com as suas normas constitucionais e com as disposições desta Convenção, as medidas legislativas ou de outra natureza que forem necessárias para tornar efetivos tais direitos e liberdades. ORGANIZAÇÃO DOS ESTADOS AMERICANOS. Convenção Americana sobre Direitos Humanos (Pacto de San José da Costa Rica). San José, 1969. Disponível em: < https://www.cidh.oas.org/basicos/portugues/c.convencao_americana.htm>. Último acesso: 30 agosto 2016.

32 Artigo 29. Normas de interpretação: Nenhuma disposição desta Convenção pode ser interpretada no sentido de: a. permitir a qualquer dos Estados Partes, grupo ou pessoa, suprimir o gozo e exercício dos direitos e liberdades reconhecidos na Convenção ou limitá-los em maior medida do que a nela prevista; b. limitar o gozo e exercício de qualquer direito ou liberdade que possam ser reconhecidos de acordo com as leis de qualquer dos Estados Partes ou de acordo com outra convenção em que seja parte um dos referidos Estados; c. excluir outros direitos e garantias que são inerentes ao ser humano ou que decorrem da forma democrática representativa de governo; e d. excluir ou limitar o efeito que possam produzir a Declaração Americana dos Direitos e Deveres do Homem e outros atos internacionais da mesma natureza. Ibidem.

${ }^{33}$ Article 26. "PACTA SUNT SERVANDA" Every treaty in force is binding upon the parties to it and must be performed by them in good faith. Article 27. INTERNAL LAW AND OBSERVANCE OF TREATIES A party may not invoke the provisions of its internal law as justification for its failure to perform a treaty. This rule is without prejudice to article 46. ORGANIZAÇÃO DAS NAÇÕES UNIDAS. Op. Cit
}

Revista de Direito Brasileira | São Paulo, SP | v. 17 | n. 7 | p. 18 - 39 | Mai./Ago. 2017 
a Boa-Fé na aplicação dos tratados e a proibição de um Estado se valer de suas normas internas para não aplicar as diposições de um diploma internacional. A doutrina aponta ainda a importância do artigo 25 da $\mathrm{CADH}^{34}$, dispondo que este artigo garante a possibilidade do indivíduo recorrer ao judiciário contra violações de seus direitos garantidos na Convenção ou o ordenamento jurídico interno do Estado $^{35}$.

O Controle de Convencionalidade começou a ser enxergado no plano do Sistema Interamericano de Direitos Humanos a partir de alguns julgados da Corte Interamericana de Direitos Humanos que vem realizando o controle do direito estatal frente à Convenção Americana sobre Direitos Humanos. Destacam-se nesse ponto os casos Myrna Mack Chang Vs. Guatemala $^{36}$ e Almocinad Arellano Vs. Chile ${ }^{37}$. Neste primeiro, foi inaugurada, no contexto da CtIDH, a expressão "Controle de Convencionalidade", em voto do juiz Sergio Garcia Ramírez ${ }^{38}$. Segundo o referido juiz, a expressão caracteriza o papel da CIDH ao adequar os atos dos Estados à ordem internacional:

En cierto sentido, la tarea de la Corte se asemeja a la que realizan los tribunales constitucionales. Estos examinan los actos impugnados -disposiciones de alcance general-- a la luz de las normas, los principios y los valores de las leyes fundamentales. La Corte Interamericana, por su parte, analiza los actos que llegan a su conocimiento en relación con normas, principios y valores de los tratados en los que funda su competencia contenciosa. Dicho de otra manera, si los tribunales constitucionales controlan la "constitucionalidad", el tribunal internacional de derechos humanos resuelve acerca de la "convencionalidad" de esos actos. Através del control de constitucionalidad, los órganos internos procuran conformar la actividad del poder público --y, eventualmente, de otros agentes sociales-- al orden que entraña el Estado de Derecho en una sociedad democrática. El tribunal interamericano, por su parte, pretende conformar esa actividad al orden internacional acogido en la convención fundadora de la jurisdicción interamericana y aceptado por los Estados partes en ejercicio de su soberanía. ${ }^{39}$

\footnotetext{
${ }^{34}$ Artigo 25. Proteção judicial: 1.Toda pessoa tem direito a um recurso simples e rápido ou a qualquer outro recurso efetivo, perante os juízes ou tribunais competentes, que a proteja contra atos que violem seus direitos fundamentais reconhecidos pela constituição, pela lei ou pela presente Convenção, mesmo quando tal violação seja cometida por pessoas que estejam atuando no exercício de suas funções oficiais. 2. Os Estados Partes comprometem-se: a. a assegurar que a autoridade competente prevista pelo sistema legal do Estado decida sobre os direitos de toda pessoa que interpuser tal recurso; b. a desenvolver as possibilidades de recurso judicial; e c. a assegurar o cumprimento, pelas autoridades competentes, de toda decisão em que se tenha considerado procedente o recurso. ORGANIZAÇÃO DOS ESTADOS AMERICANOS. Op. Cit..

${ }^{35}$ MAC-GREGOR ,Eduardo Ferrer, Conventionality Control: The New Doctrine of the Inter-American Court of Human Rights, American Journal of International Law Unbound, 93, 2015, p.97. Disponível em: < https://www.asil.org/sites/default/files/Ferrer\%20Mac-Gregor\%2C\%20Conventionality\%20Controlv3.pdf>. Último acesso: 30 agosto 2016.

${ }^{36}$ CORTE INTERAMERICANA DE DIREITOS humANOS. Caso Myrna Mack Chang Vs. Guatemala. Sentença de 25 de novembro de 2003 , série c, $\mathrm{n}^{\circ} 101$.

37 CORTE INTERAMERICANA DE DIREITOS humANOS. Caso Almonacid Arellano y otros Vs. Chile. Fondo, Reparaciones y Costas. Sentença de 26 de setembro de 2006, série c, no 154.

${ }_{38}$ MARTINS, Leonardo; MOREIRA, Thiago Oliveira. Constitucionalidade e Convencionalidade de Atos do Poder Público: concorrência ou hierarquia? Um contributo em face da situação jurídico constitucional brasileira. Anuario de Derecho Constitucional Latinoamericano, AÑO XVII, Montevideo, 2011, p. 471.

${ }^{39}$ CORTE INTERAMERICANA DE DIREITOS HUMANOS. Caso Tibi Vs. Ecuador. Sentença de 07 de setembro de 2004.
}

Revista de Direito Brasileira | São Paulo, SP | v. 17 | n. 7 | p. 18 - 39 | Mai./Ago. 2017 
Em caso subsequente, também sob a presidência do Juiz Sergio Ramírez, o pleno da Corte Interamericana utilizou pela primeira vez a expressão "Controle de Convencionalidade" ao proferir a obrigação dos juízes nacionais em aplicar as leis nacionais em conformidade com a Convenção Americana sobre Direitos Humanos.

La Corte es consciente que los jueces y tribunales internos están sujetos al imperio de la ley y, por ello, están obligados a aplicar las disposiciones vigentes en el ordenamiento jurídico. Pero cuando un Estado ha ratificado un tratado internacional como la Convención Americana, sus jueces, como parte del aparato del Estado, también están sometidos a ella, lo que les obliga a velar porque los efectos de las disposiciones de la Convención no se vean mermadas por la aplicación de leyes contrarias a su objeto y fin, y que desde un inicio carecen de efectos jurídicos. En otras palabras, el Poder Judicial debe ejercer una especie de "control de convencionalidad" entre las normas jurídicas internas que aplican en los casos concretos y la Convención Americana sobre Derechos Humanos. En esta tarea, el Poder Judicial debe tener en cuenta no solamente el tratado, sino también la interpretación que del mismo ha hecho la Corte Interamericana, intérprete última de la Convención Americana. ${ }^{40}$

Destaca-se que mesmo antes da Corte Interamericana denominar esta ferramenta como Controle de Convencionalidade, ela já era exercida pelo tribunal ${ }^{41}$, como exemplifica o o caso A Última Tentação de Cristo ${ }^{42}$ em que a CtIDH determinou que o Chile deveria reformar sua Constituição por ser esta violadora ao Direito de Liberdade de Expressão e Pensamento garantido no artigo 13 da Convenção Americana de Direitos Humanos.

Em geral, o Controle de Convencionalidade é realizado por tribunais internacionais de Direitos Humanos, destacando-se as Cortes Europeia, Interamericana e Africana de Direitos Humanos. Isto ocorre para evitar que ao mesmo tempo os Estados sejam fiscais e fiscalizados ${ }^{43}$. Mas como se percebe através do Caso Almocinad Arellano Vs. Chile, esse Controle realizado pela CtIDH sofreu um alargamento com o fundamento de que os próprios magistrados internos de um país estariam submetidos às disposições da Convenção Interamericana de Direitos Humanos. Portanto, o entendimento da CtIDH passou a ser de que o Controle de Convencionalidade poderia ser feito pela compatibilização realizada pelos juízes nacionais, servindo como uma forma de compensar o pequeno número de casos que são julgados pela CtIDH e passam pelo Controle de Convencionalidade concentrado ${ }^{44}$.

Como assevera André de Carvalho Ramos, o Controle de Convencionalidade realizado pelo juiz nacional é preliminar ou provisório, pois mesmo se for concretizado, não vincula o juiz

40 CORTE INTERAMERICANA DE DIREITOS HUMANOS. Caso Almonacid Arellano y otros Vs. Chile. Fondo, Reparaciones y Costas. Sentença de 26 de setembro de 2006, série c, no 154.

${ }^{41}$ SÁGUES, Nestor Pedro. El “control de convencionlad" em el sistema interamericano, y sus anticipos em el âmbito de los derechos econômico-sociales. Concordancias y diferencias com el sistema europeo. Instituto de Investigaciones Juridicas, 2012, p.382. Disponível <http://www.ijf.cjf.gob.mx/cursosesp/2012/derhumancontrolconvencionalidad/Nestor\%20Sagues.pdf>. Último acesso em: 08 junho 2016.

${ }^{42}$ CORTE INTERAMERICANA DE DIREITOS HUMANOS. Caso "La Última Tentación de Cristo" (Olmedo Bustos y otros) Vs. Chile. Fondo, Reparaciones y Costas. Sentença de 5 de fevereiro de 2001, série c, nº 73.

${ }^{43}$ RAMOS, André de Carvalho. Op. Cit. p.57.

${ }^{44}$ BINDER, Christina. The prohibition of amnesties by the inter-american court of human rights. German Law Jornal, v 12, n. 5, 2010, p. 1215. Disponível em: 〈http://www.corteidh.or.cr/tablas/r26381.pdf〉. Último acesso em: 08 junho 2016.

Revista de Direito Brasileira | São Paulo, SP | v. 17 | n. 7 | p. 18 - 39 | Mai./Ago. 2017 
internacional $^{45}$. Desta forma, todo ato jurisdicional está apto a realizar o Controle de Convencionalidade, devendo ser suscitado como questão preliminar no caso concreto. A necessidade de ser arguida como questão preliminar não impede que o órgão julgador declare de ofício a inconvencionalidade da lei ou ato do poder público ${ }^{46}$. Ademais, a CtIDH já se posicionou, em voto do juiz Sergio Ramírez, sobre a necessidade de realização do Controle de Convencionalidade ex officio:

En otras palabras, los órganos del Poder Judicial deben ejercer no sólo un control de constitucionalidad, sino también "de convencionalidad" ex officio entre las normas internas y la Convención Americana, evidentemente en el marco de sus respectivas competencias y de las regulaciones procesales correspondientes. Esta función no debe quedar limitada exclusivamente por las manifestaciones o actos de los accionantes en cada caso concreto, aunque tampoco implica que ese control deba ejercerse siempre, sin considerar otros presupuestos formales y materiales de admisibilidad y procedencia de ese tipo de acciones $^{47}$.

O Controle de Convencionalidade realizado pelos Estados foi expressamente defendido pela CIDH no caso Trabajadores Cesados Del Congreso (Aguado Alfaro y otros) vs. Peru na sentença de 2006 que prevê:

Cuando un Estado ha ratificado un tratado internacional como la Convención Americana, sus jueces también están sometidos a ella, lo que les obliga a velar porque el efecto útil de la Convención no se vea mermado o anulado por la aplicación de leyes contrarias a sus disposiciones, objeto y fin. En otras palabras, los órganos del Poder Judicial deben ejercer no sólo un control de constitucionalidad, sino también "de convencionalidad" ex officio entre las normas internas y la Convención Americana, evidentemente en el marco de sus respectivas competencias y de las regulaciones procesales correspondientes. Esta función no debe quedar limitada exclusivamente por las manifestaciones o actos de los accionantes en cada caso concreto, aunque tampoco implica que ese control deba ejercerse siempre, sin considerar otros presupuestos formales y materiales de admisibilidad y procedencia de ese tipo de acciones ${ }^{48}$.

Considera-se difuso esta modalidade de Controle de Convencionalidade justamente por implicar que todos os juízes nacionais o apliquem, contrastando assim com o Controle de Convencionalidade concentrado realizado pela CtIDH. Assim, a aplicação do Controle de Convencionalidade pelos juízes nacionais dos Estados membros nasce de uma construção jurisprudencial da própria $\mathrm{CtIDH}$, uma mutação interpretativa do artigo 69 da Convenção

\footnotetext{
${ }^{45}$ RAMOS, André de Carvalho. Op. Cit. p.58

${ }^{46}$ FERNANDES, Bernardo Gonçalves. Op. Cit, p.1229

${ }^{47}$ CORTE INTERAMERICANA DE DIREITOS HUMANOS. Caso Trabajadores Cesados del Congreso (Aguado Alfaro y otros) Vs. Perú. Fondo, Reparaciones y Costas. Sentença de 24 de novembro de 2006, série c, $\mathrm{n}^{\circ}$ 158.

${ }^{48}$ CORTE INTERAMERICANA DE DIREITOS HUMANOS. Caso Trabajadores Cesados del Congreso (Aguado Alfaro y otros) Vs. Perú. Fondo, Reparaciones y Costas. Sentença de 24 de novembro de 2006, série c, ${ }^{\circ}$ 158.
} 
Americana $^{49}$ com o objetivo de se fortalecer o sistema interamericano de Direitos Humanos. Sua fundamentação jurídica se baseia em três aspectos: i) a boa-fé dos Estados no cumprimento de suas obrigações internacionais; ii) o princípio do efeito útil dos tratados que não pode ser diminuída pela normas internas; iii) a impossibilidade de se alegar o direito interno para evitar o cumprimento das normas internacionais, conforme o artigo 27 da Convenção de Viena sobre o Direito dos Tratados (1969) ${ }^{50}$.

Segundo Eduardo Mac-Gregor, o Controle de Convencionalidade difuso transforma o juiz nacional em um juiz interamericano, de forma que este se torna um guardião da Convenção Americana sobre Direitos Humanos, seus protocolos adicionais, de outros tratados e da jurisprudência da $\mathrm{CtIDH}^{51}$. Daí se depreende a ideia de um bloco de convencionalidade, pois, como se pode notar, a adequação dos atos e leis internas deve ser conforme o conjunto de compromissos estabelecidos pelo país em matéria de Direitos Humanos.

En la especie, al referirse a un "control de convencionalidad" la Corte Interamericana ha tenido a la vista la aplicabilidad y aplicación de la Convención Americana sobre Derechos Humanos, Pacto de San José. Sin embargo, la misma función se despliega, por idénticas razones, en lo que toca a otros instrumentos de igual naturaleza, integrantes del corpus juris convencional de los derechos humanos de los que es parte el Estado: Protocolo de San Salvador, Protocolo relativo a la Abolición de la Pena de Muerte, Convención para Prevenir y Sancionar la Tortura, Convención de Belém do Pará para la Erradicación de la Violencia contra la Mujer, Convención sobre Desaparición Forzada, etcétera. De lo que se trata es de que haya conformidad entre los actos internos y los compromisos internacionales contraídos por el Estado, que generan para éste determinados deberes y reconocen a los individuos ciertos derechos. $^{52}$

Posteriormente, a Corte se manifestou no caso Gelman vs. Uruguay ${ }^{53}$ sobre o dever de todas as autoridades estatais, e não apenas os juízes, realizarem o Controle de Convencionalidade difuso, utilizando-se da interpretação da própria $\mathrm{CtIDH}$ ao aplicarem a CADH. O posicionamento foi mantido na Opinião Consultiva 21 de $2014^{54}$ em que a Corte afirmou que a violação por quaisquer dos órgãos estatais às disposições da $\mathrm{CADH}$ acarreta a responsabilização internacional e que, por isso, devem realizar o Controle de Convencionalidade com relação às considerações da Corte em seus pronunciamentos não contenciosos, mesmo que o Estado não tenha sido parte do caso em questão. Este posicionamento da CtIDH se justifica por ser ela a

\footnotetext{
${ }^{49}$ LARRIEUX, Jorge T. Caso Gelman vs. Uruguay. Justicia transicional, Corte Interamericana de Derechos Humanos y el control de convencionalidad. Anuário de Derecho Constitucional Latinoamericano, ano XIX, 2013, p. 601. Disponível em: < http://www.juridicas.unam.mx/publica/librev/rev/dconstla/cont/2013/pr/pr33.pdf>. Último acesso: 08 de junho de 2016.

${ }^{50}$ SÁGUES, Nestor Pedro. Op. Cit.. p.383/384.

51 MAC-GREGOR, Eduardo Ferrer. Interpretación conforme y control difuso de convencionalidad el nuevo paradigma para el juez mexicano. In MARINONI, Luiz Guilherme; MAZZUOLI, Valerio de Oliveira (Org.). Controle de Convencionalidade: um panorama latino-americano: Brasil, Argentina, Chile, México, Peru, Uruguai. Brasília, DF: Gazeta Jurídica, 2013, p. 594.

52 CORTE INTERAMERICANA DE DIREITOS HUMANOS. Caso Trabajadores Cesados del Congreso (Aguado Alfaro y otros) Vs. Perú. Fondo, Reparaciones y Costas. Sentença de 24 de novembro de 2006, série c, $\mathrm{n}^{\circ}$ 158.

${ }^{53}$ CORTE INTERAMERICANA DE DIREITOS HUMANOS. Caso Gelman vs. Uruguay. Fondo, Reparaciones. Sentença de 24 de fevereiro de 2011, parágrafo 193.

${ }^{54}$ CORTE INTERAMERICANA DE DIREITOS HUMANOS. Advisory Opinion OC-21/14. Opinião Consultiva de 19 agosto 2014.
}

Revista de Direito Brasileira | São Paulo, SP | v. 17 | n. 7 | p. 18 - 39 | Mai./Ago. 2017 
última intérprete da Convenção Americana de Direitos Humanos e suas disposições refletirem o conteúdo da $\mathrm{CADH}^{55}$.

Como esclarecem Martins e Moreira, a CtIDH, realizando o controle concentrado, não revoga a lei inconvencional ou cria norma para cuidar daquela relação levada à Corte, ela apenas declara a inconvencionalidade e determina que o Estado conforme sua legislação aos compromissos assumidos em matéria de Direitos Humanos, sob pena de responsabilização ${ }^{56}$. Este posicionamento da Corte pode ser visualizado nos casos em que se analisa leis de anistia, como os casos Barrios Altos ${ }^{57}$, La Cantuta ${ }^{58}$, Gomes Lund $^{59}$ e Almocinad Arellano ${ }^{60}$. Nestas oportunidades, a CtIDH declarou que as leis de anistia dos países em julgamento carecem de efeito legal diante da Convenção Americana de Direitos Humanos, não apenas declarando a responsabilidade do Estado, mas também a invalidade da lei, comportando-se, segundo Cassese, como um verdadeiro tribunal constitucional ${ }^{61}$. Vê-se assim claramente a supremacia das decisões da CtIDH sobre os ordenamentos nacionais e o dever dos Estados de adaptarem suas normas aos tratados do Sistema Interamericano de Direitos Humanos (Controle de Convencionalidade) ${ }^{62}$.

A perspectiva do Estado Constitucional e Humanista de Direito rechaça a ideia de validade da lei pela simples vigência, como afirmava a concepção positivista legalista, Kelseniana, não se confundindo vigência e validade. Segundo Ferrajolli, a vigência se liga aos requisitos formais da norma, ao passo que a validade corresponderia à compatibilidade com o

55 DULITZKY, Ariel E. An Inter-American Constitutional Court? The invention of the Conventionality Control by the Inter-American Court of Human Rights. Texas International Law Journal, vol. 50, 2015. Disponível em: < https://law.utexas.edu/faculty/adulitzky/69-inter-amer-constitutional-court.pdf>. Último acesso: 30 agosto

2016.

El control de convencionalidad "nacional”, o "de abajo”, es además rea-firmado por la Corte Interamericana en una familia de casos: La Cantuta (29 denoviembre de 2006, considerando 173), Boycevs. Barbados(20denoviem- bre de 2007, considerando 78), Fermín Ramírez y Raxcacó Reyes (9 de mayo de 2008, considerando 63), Heliodoro Portugal (12 de agosto de 2008, consideran- dos 180/1), Manuel Cepeda Vargas (26 de mayo de 2010, considerando 208 y nota 307), Comunidad Indígena Xákmok ftásek (24 de agosto de 2010, conside- rando 311), Fernández Ortega (30 de agosto de 2010, considerando 237). Ro- sendo Cantú(31 de agosto de 2010, considerandos 219 y 220), Ibsen Cárdenasy otro (1o. de septiembre de 2010, considerando 202), Velez Loor (23 de no-viembre de 2010, considerando 287), Gomes Lund (24 de noviembre de 2010, considerando 176), y Cabrera Garcia-Montiel Flores (26 de noviembre de 2010, considerando 225). Es muy importante en este caso, asimismo, el voto con-currente y razonado del juez ad hoc Eduardo FerrerMac Gregor, ya que incluye un pormenorizado estudio de la doctrina y jurisprudencia del control de convencionalidad). La doctrina se ratifica, por ejemplo, en Gel- man (2011). SÁGUES, Nestor Pedro. Op. Cit p.383-384..

${ }^{56}$ MARTINS, Leonardo; MOREIRA, Thiago Oliveira. Constitucionalidade e Convencionalidade de Atos do Poder Público: concorrência ou hierarquia? Um contributo em face da situação jurídico constitucional brasileira. Anuario de Derecho Constitucional Latinoamericano, AÑO XVII, Montevideo, 2011, pp. 463 -483.

${ }^{57}$ CORTE INTERAMERICANA DE DIREITOS HUMANOS. Caso Barrios Altos Vs. Perú. Sentença de 14 de março de 2001.

${ }^{58}$ CORTE INTERAMERICANA DE DIREITOS HUMANOS. Caso La Cantuta Vs. Perú. Fondo, Reparaciones y Costas. Sentença de 29 de nov. 2006.

${ }^{59}$ CORTE INTERAMERICANA DE DIREITOS HUMANOS. Caso Gomes Lund e Outros ("Guerrilha do Araguaia") vs. Brasil. Sentença de 24 nov. 2010.

${ }^{60}$ CORTE INTERAMERICANA DE DIREITOS HUMANOS. Caso Almonacid Arellano y otros Vs. Chile. Fondo, Reparaciones y Costas. Sentença de 26 de setembro de 2006, série c, no 154.

${ }^{61}$ It is the first time that an international court determines that national laws are devoid of legal effects within the State system where they have been adopted and consequently obliges the State to act as if these laws have never been enacted. CASSESE, Antonio apud MAC-GREGOR, Eduardo Ferrer. DOMÍNGUEZ, Pablo González. Death Penalty, Amnesty Laws, and Forced Disappearances: Three Main Topics of the InterAmerican Corpus Juris in Criminal Law. Notre Dame Journal of International \& Comparative Law: Vol. 5: Iss. 1, Article 4, p.88. Disponível em: <http://scholarship.law.nd.edu/cgi/viewcontent.cgi?article=1029\&context=ndjicl>. Último acesso: 08 junho 2016.

${ }^{62}$ BINDER, Christina. Op. Cit, p. 1212.

Revista de Direito Brasileira | São Paulo, SP | v. 17 | n. 7 | p. 18 - 39 | Mai./Ago. 2017 
aspecto substancial das demais normas ${ }^{63}$. Desta forma, as normas que se ligam à produção legislativa não são só formais, mas também substanciais, como o respeito aos direitos fundamentais.

A lei pode assim ser vigente sem ser válida, mas não válida sem ser vigente. Somente a norma que for vigente e válida será eficaz. Assim já se pronunciou Valério Mazzuoli:

Apenas havendo compatibilidade vertical material com ambas as normas - a Constituição e os tratados - é que a norma infraconstitucional em questão será vigente e válida (e, consequentemente, eficaz). Caso contrário, não passando a lei pelo exame da compatibilidade vertical material com os tratados (segunda análise de compatibilidade), a mesma não terá qualquer validade (e eficácia) no plano do direito interno brasileiro, devendo ser rechaçada pelo juiz no caso concreto. $^{64}$

No mesmo sentido já asseverava Miguel Reale ao propor:

[...] que todas as fontes operam no quadro de validade traçado pela Constituição de cada país, e já agora nos limites permitidos por certos valores jurídicos transnacionais, universalmente reconhecidos como invariantes jurídicoaxiológicas,como a Declaração Universal dos Direitos do Homem ${ }^{65}$

Os tratados servem assim como limites verticais, substanciais, à produção normativa, bem como a Constituição. Há assim o Controle de Constitucionalidade e de Convencionalidade das normas. Mazzuoli ainda defende que as normas supralegais servem também como limite ${ }^{66}$. Conforme a ideia de supralegalidade dos tratados de Direitos Humanos, uma lei anterior a um tratado, conflitante com este, seria automaticamente revogada ao tempo da entrada em vigor deste último. Sendo a lei posterior ao tratado, esta seria vigente, mas não válida, devendo ser aplicado o Controle de Convencionalidade.

O Controle de Convencionalidade tem provocado mudanças na relação entre os Estados e o Direito Internacional, tome-se como exemplo o México. O Estado Mexicano realizou alterações em sua Constituição, promulgadas em julho de 2011, como forma de abarcar expressamente o Controle de Convencionalidade difuso. Após as mudanças legislativas, a Constituição Mexicana passou a constar o seguinte texto em seu artigo $1^{\circ}$ :

En los Estados Unidos Mexicanos todas las personas gozarán de los derechos humanos reconocidos en esta Constitución y en los tratados internacionales de los que el Estado Mexicano sea parte, así como de las garantías para su protección, cuyo ejercicio no podrá restringirse ni suspenderse, salvo en los casos y bajo las condiciones que esta Constitución establece.

Las normas relativas a los derechos humanos se interpretarán de conformidad con esta Constitución y con los tratados internacionales de la materia favoreciendo en todo tiempo a las personas la protección más amplia.

Todas las autoridades, en el ámbito de sus competencias, tienen la obligación de promover, respetar, proteger y garantizar los derechos humanos de

\footnotetext{
${ }^{63}$ FERRAJOLI, Luigi. Derechos y garantias: la ley Del más débil, apud MAZZUOLI, Valério de Oliveira. Teoria Geral do Controle de Convencionalidade no Direito Brasileiro. Revista da Associação dos Juízes do Rio Grande do Sul, ano XXXVI, n 113,2009 , p. 337.

${ }^{64}$ MAZZUOLI, Valerio de Oliveira. Teoria Geral do Controle de Convencionalidade no Direito Brasileiro. Revista da Associação dos Juízes do Rio Grande do Sul, ano XXXVI, nº 113, 2009, p. 341.

${ }^{65}$ REALE, Miguel. Fontes e modelos do direito: para um novo paradigma hermenêutico. São Paulo: Saraiva, 1994, p. 13, apud , MAZZUOLI, Valério de Oliveira, Op. Cit., 2009, p. 342.

${ }^{66}$ MAZZUOLI, Valerio de Oliveira. Op. Cit, 2009, p. 345.

Revista de Direito Brasileira | São Paulo, SP | v. 17 | n. 7 | p. 18 - 39 | Mai./Ago. 2017
} 
conformidad con los principios de universalidad, interdependencia, indivisibilidad y progresividad. En consecuencia, el Estado deberá prevenir, investigar, sancionar y reparar las violaciones a los derechos humanos, en los términos que establezca la ley. ${ }^{67}$

Com estas disposições, o Estado Mexicano se adéqua à posição da $\mathrm{CtIDH}$, garantindo a observância dos Tratados de Direitos Humanos e consequentemente o Controle de Convencionalidade difuso a ser realizado por todos os juízes nacionais. Esta mudança legislativa permite a comparação com a situação apresentada pelo Brasil, servindo como fonte aos questionamentos produzidos acerca de sua aplicação.

Também no caso Argentino, a escolha se justifica pela aceitação da doutrina e jurisprudência acerca do tema aqui tratado. Em mais de uma oportunidade, a Corte Suprema de Justicia já se posicionou favoravelmente à aplicação do Controle de Convencionalidade difuso. Este é, por exemplo, o Caso Mazzeo, Julio Lilo e outros com sentença proferida em 13 de julho de 2007:

Que por su parte, La Corte Interamericana há señalado que "es consciente que los jueces y tribunales internos estánsujetos al império de La ley y, por ello, están obligados a aplicar las disposiciones vigentes en el ordenamiento jurídico. Pero cuando um Estado há ratificado um tratado internacional como La Convención Americana, sus jueces, como parte del aparato del Estado, también están sometidos a ella, ló que lês obliga a velar porque lós efectos de las disposiciones de La Convención no se vean mermados por La aplicación de leyes contrarias a su objeto y fin, y que desde su inicio carecen de efectos jurídicos. Em otras palabras, el Poder Judicial debe ejercer uma espécie de "control de convencionalidad" entre las normas jurídicas internas que aplican em lós casos concretos y La Convención Americana sobre Derechos Humanos. Em esa tarea, el Poder Judicial debe tener em cuenta no solamente el tratadim sino también La interpretación que del mismo ha hecho la Corte Interamericana, intérprete última de La Convención Americana (CIDH, Serie C $N^{\circ} 154$, caso “Almocinad”, del 26 septiembre de 2006, parágraf. 124). ${ }^{68}$

Como se depreende, o estudo do Controle de Convencionalidade é essencial para a adequação dos atos normativos nacionais às disposições da $\mathrm{CtIDH}$, devendo ainda ser encarado como uma forma de garantia da aplicação dos Direitos Humanos por nosso país.

\section{A APLICAÇÃO DO CONTROLE DE CONVENCIONALIDADE PELOS JUÍZES NACIONAIS}

A doutrina do Controle de Convencionalidade ainda dá seus primeiros passos quanto à sua aplicação pelos juízes nacionais, no entanto as decisões que citam o presente instrumento tem se multiplicado. Cite-se como exemplo o Habeas Corpus $\mathrm{N}^{\circ} 1.358 .323-2$ julgado pelo Tribunal de Justiça do Estado do Paraná que utilizou da Convenção Americana de Direitos Humanos e do

67 MÉXICO. Constitución Política de los Estados Unidos Mexicanos de 1917. Disponível em: <http://www.ordenjuridico.gob.mx/Constitucion/cn16.pdf>. Último acesso: 04 de abril de 2016.

${ }^{68}$ ARGENTINA. Corte Suprema de Justicia. Mazzeo, Julio Lilo y otros s/ rec. de casación e inconstitucionalidad. Sentença de 13 de julho de $2007 . \quad$ Disponível em: http://www.csjn.gov.ar/jurisp/jsp/fallos.do?usecase=mostrarDocumento\&falloId=1951>. Último acesso: 04 de abril de 2016. 
Controle de Convencionalidade para se posicionar acerca da necessidade de audiência de custódia no processo penal brasileiro. Veja-se:

HABEAS CORPUS - TRÁFICO DE DROGAS - DENÚNCIA PELO ARTIGO 33, CAPUT DA LEI $\mathrm{N}^{\circ} 11.343 / 06$ - PRISÃO EM FLAGRANTE CONVERTIDA EM PREVENTIVA - AUDIÊNCIA DE CUSTÓDIA PREVISÃO EM PACTOS E TRATADOS INTERNACIONAIS RATIFICADOS PELO BRASIL - CONTROLE DE CONVENCIONALIDADE - EFETIVAÇÃO DOS DIREITOS HUMANOS PREVISTOS NA ORDEM INTERNACIONAL - REQUISITOS DA PRISÃO - FUNDAMENTAÇÃO COM BASE NA QUANTIA CONSIDERÁVEL DE DROGAS - AUSÊNCIA DE MELHOR TÉCNICA - FALTA DE CONEXÃO LÓGICA QUANTIDADE CONCRETAMENTE APREENDIDA QUE NÃO SE REVELA EXPRESSIVA - AUSÊNCIA DE PERIGO CONCRETO MEDIDAS CAUTELARES ALTERNATIVAS - CIRCUNSTÂNCIAS DO CASO QUE INDICAM A NECESSIDADE E ADEQUAÇÃO DE SUA APLICAÇÃO - ARTIGO 282 DO CÓDIGO DE PROCESSO PENAL ORDEM CONHECIDA E CONCEDIDA POR UNANIMIDADE. 1. Dispõe o artigo $7^{\circ}$, item 5, da Convenção Americana de Direitos Humanos que "Toda pessoa detida ou retida deve ser conduzida, sem demora, à presença de um juiz ou outra autoridade autorizada pela lei a exercer funções judiciais (...)". No mesmo sentido assegura o artigo $9^{\circ}$, item 3, do Pacto Internacional de Direitos Civis e Políticos que "Qualquer pessoa presa ou encarcerada em Documento assinado digitalmente, conforme MP n. ${ }^{\circ} 2.200-2 / 2001$, Lei n. ${ }^{\circ} 11.419 / 2006 \mathrm{e}$ Resolução n. ${ }^{\circ}$ 09/2008, do TJPR/OE O documento pode ser acessado no endereço eletrônico http://www.tjpr.jus.br Página 2 de 20 Habeas Corpus Crime $\mathrm{n}^{\circ}$ 1.358.323-2 fls. 2 virtude de infração penal deverá ser conduzida, sem demora, à presença do juiz ou de outra autoridade habilitada por lei a exercer funções judiciais (...)". 2. "Isto porque os direitos humanos são extraídos dos tratados de direitos humanos ratificados pelo Brasil, e, por isso, não se exige da jurisdição apenas um controle de constitucionalidade, com vistas a efetivar os direitos previstos na Constituição, mas também um controle de convencionalidade, com o objetivo de efetivar os direitos humanos previstos na ordem internacional". 3. "Nesse contexto, o controle de convencionalidade das leis pela jurisdição contribui para que os direitos humanos previstos nos tratados internacionais sejam incorporados às decisões judiciais, permitindo a interiorização deste consenso por meio das decisões judiciais. Deste modo, a jurisdição constitucional funciona como instrumento potencializador da efetividade dos direitos humanos, na medida em que, a partir da compreensão crítica da realidade, sob o prisma direitos humanos, aplica este consenso no âmbito interno, operando, assim, como ferramenta de transformação social". $(\ldots)^{69}$

Como se conclui, a referida decisão, baseada no Controle de Convencionalidade interpretou nossas normas internas de forma que fosse realizada a audiência de custódia, conforme previsão da Convenção Americana de Direitos Humanos.

A decisão mais recente a ganhar repercussão pela aplicação do Controle de Convencionalidade foi proferida por um magistrado da Comarca de Belford Roxo ${ }^{70}$, Rio de

\footnotetext{
${ }^{69}$ BRASIL. Tribunal de Justiça do Paraná. Habeas Corpus $\mathbf{N}^{\mathbf{0}}$ 1.358.323-2, $3^{\mathrm{a}}$ Vara Criminal do Foro Central da Comarca da Região Metropolitana de Curitiba, Curitiba, PR, DJ 23.04.2015. Disponível em: <https://www.tjpr.jus.br/documents/18319/5218101/Processo_N\%C2\%BA_1358323-2_-_HC_Crime.pdf>. Última visita: 04 de abril de 2016.

${ }^{70}$ BRASIL. Tribunal de Justiça do Rio de Janeiro. Processo no 0013156-07.2015.8.19.0008. $2^{\mathrm{a}}$ Vara Criminal da Comarca de Beldford Roxo, Beldford Roxo, RJ, DJ 04.07.2016. Disponível em: < Revista de Direito Brasileira | São Paulo, SP | v. 17 | n. 7 | p. 18 - 39 | Mai./Ago. 2017
} 
Janeiro, que, diante de um caso de suposto desacato, declarou que este crime é incompatível com as disposições do artigo 13 da Convenção Americana de Direitos Humanos e a Declaração de Princípios sobre Liberdade de Expressão aprovada no âmbito da CIDH, deixando de aplicá-lo. Segundo o magistrado do referido caso, a Declaração de Princípios sobre a Liberdade de Expressão estabelece em seu artigo 11 que as leis de desacato atentam contra a liberdade de expressão e o direito à informação.

A sentença proferida ainda destaca que o Brasil não pode aplicar sua norma interna em detrimento dos tratados por ele ratificados, conforme dispõe o artigo 27 da Convenção de Viena sobre o Direito dos Tratados.

Outra decisão na mesma esteira foi proferida na ação penal $n^{0}$ 006737064.2012.8.24.0023 da comarca Florianópolis, TJSC ${ }^{71}$, em que magistrado, citando também a Declaração de Princípios sobre a Liberdade de Expressão e o Controle de Convencionalidade deixou de aplicar artigo do 331 do Código Penal Brasileiro que trata sobre o desacato.

Destaca-se que a CtIDH já se manifestou acerca da incompatibilidade do crime de desacato com as disposições do artigo 13 da CADH no caso denominado "Palamara Iribarne Vs. Chile" 72 .

Por outro lado, o Brasil não tem cumprido inteiramente as decisões proferidas pela Corte Interamericana de Direitos Humanos baseadas no Controle de Convencionalidade. No caso Gomes Lund e outros (Guerrilha do Araguaia), que trata sobre a Lei de Anistia brasileira, a CtIDH decidiu que o Brasil deveria determinar as responsabilidades penais e aplicar as sanções e consequências previstas pelo direito penal, adequando para isso o direito interno no que fosse preciso, em confronto direto com a Lei de Anistia ( $\mathrm{N}^{\mathrm{o}}$ 6.683/79). Isso significaria, consequentemente, anular a aplicação da referida lei.

O Brasil, por sua vez, instaurou a Comissão da Verdade com o intuito de atender às determinações da Corte. No entanto, a lei instituidora da Comissão (Lei 12528/11), em seu artigo $4^{\circ}, \S 4^{\circ}$, estabelece que esta não tem caráter jurisdicional ou persecutório, ferindo o disposto pela sentença da CtIDH.

Em sua resolução de cumprimento da sentença a CtIDH declarou, no ano de 2014, que o Brasil não estaria cumprindo com a determinação de investigar os crimes praticados durante a ditadura militar e que a Lei de Anistia não poderia continuar a ser um obstáculo, como ainda se apresentava $^{73}$.

Vê se, portanto, que a aplicação do Controle de Convencionalidade tem evoluído à passos lentos na jurisdição interna, mas que a sua aplicação já demonstra sinais de melhor aplicação.

http://emporiododireito.com.br/juiz-do-tjrj-faz-controle-de-convencionalidade-do-crime-de-desacato/>.

Último acesso: 05 agosto 2016.

${ }^{71}$ BRASIL. Tribunal de Justiça de Santa Catarina. Ação Penal no 0067370-64.2012.8.24.0023. $4^{\text {a }}$ Vara Criminal da Comarca de Florianópolis, Florianópolis, SC, DJ 17.03.2015.

${ }^{72}$ CORTE INTERAMERICANA DE DIREITOS HUMANOS. Caso Palamara Iribarne vs. Chile. Fondo Reparaciones y Costas. Sentença de 22 de novembro de 2005.

${ }^{73} 23$. Em razão de todo o exposto, a Corte conclui que a medida de reparação relativa à obrigação de investigar os fatos do presente caso encontra-se pendente de cumprimento. Por isso, o Tribunal requer que em seu próximo relatório o Estado apresente informação atualizada e detalhada sobre: i) o estado em que se encontram as ações penais iniciadas em relação aos fatos ocorridos a respeito de seis das vítimas do presente caso, assim como se foram iniciadas novas ações penais a esse respeito; ii) as razões pelas quais não se estariam investigando os fatos violatórios em detrimento das demais vítimas deste caso, e iii) os esforços que o Estado estaria empreendendo para garantir que a interpretação e aplicação da Lei de Anistia, a prescrição e a falta de tipificação do delito de desaparecimento forçado não continuem sendo um obstáculo para o cumprimento do ordenado pela Corte no presente caso. CORTE INTERAMERICANA DE DIREITOS HUMANOS. Supervisão de Cumprimento de Sentença Caso Gomes Lund e Outros ("Guerrilha do Araguaia") vs. Brasil. Resolução de 17 de outubro de 2014. 


\section{CONCLUSÃO}

A relação entre direito interno e Direito Internacional tem se modificado ao longo do tempo, com o fortalecimento das disposições internacionais. A aplicação efetiva dos tratados e o status que estes ganharam no direito interno ilustram bem este desenvolvimento. Neste contexto, fica claro o papel do Controle de Convencionalidade. Desenvolvido em meio ao Sistema Interamericano de Direitos Humanos, este mecanismo tomou aspecto indispensável no Estado Constitucional Cooperativo.

A construção histórica do controle de convencionalidade é um testemunho claro do papel que o Direito Internacional, os Direitos Humanos e mesmo o indivíduo alcançaram no contexto atual. No mundo globalizado atual não se pode mais se suportar a ideia de tratados que são desrespeitados, o direito internacional tem servido de meios para que as obrigações estatais assumidas internacionalmente sejam cumpridas. O papel do Controle de Convencionalidade é, portanto, justamente servir como instrumento de cumprimento de tratados firmados acerca da matéria de direitos humanos, garantindo que os indivíduos tenham seus direitos efetivados.

Internamente, a posição brasileira frente aos tratados de Direitos Humanos se alterou com o fortalecimento do Direito Internacional, passando a considerá-los como possuidores de status supralegal ou constitucional, conforme o processo de internacionalização utilizado.

A doutrina e jurisprudência americana tem adotado o Controle de Convencionalidade enquanto parte do sistema estatal, como comprovam o crescente número de casos tanto em controle de convencionalidade abstrato como concentrado.

O Brasil, apesar de ainda possuir poucas decisões que se utilizam do controle de convencionalidade, tem demonstrado que este é um instrumento que alcançará maior efetividade no sistema pátrio. Este entendimento é comprovado pelas decisões judiciais que tem realizado o Controle de Convencionalidade já na primeira instância do Poder Judiciário e também pela previsão do Código de Processo Civil de respeito aos tratados ratificados pelo Estado. O Brasil, ao adotar o Controle de Convencionalidade, se insere no rol de outros países participantes do Sistema Interamericano de Direitos Humanos, como o México e Argentina, que também demonstram modificações em seu posicionamento interno e legislação para abarcar este mecanismo.

A adoção da Convenção de Viena sobre o Direito dos Tratados torna-se ainda mais claro que as relações entre o Direito Internacional e direito interno não mais podem ser tratados como participantes de dois sistemas distintos que apenas se tangenciam. Ademais, como se depreende do posicionamento da Corte Interamericana de Direitos Humanos, como no caso no caso Trabajadores Cesados Del Congreso (Aguado Alfaro y otros) v. Peru, é dever dos Estados, através dos magistrados nacionais, realizar o Controle de Convencionalidade difuso.

Assim, este sistema deve ser abarcado por toda a estrutura nacional e exercido de forma difusa, com o intuito de se fazer valer as obrigações assumidas internacionalmente pelo Estado, bem como se dar efetividade aos Direitos Humanos da população, sob pena até mesmo de responsabilização estatal.

\section{REFERÊNCIAS BIBLIOGRÁFICAS}

ACCIOLY, Hildebrando; CASELLA, Paulo Borba; SILVA, G. E. do Nascimento. Manual de Direito Internacional Público, 20 ed. São Paulo: Saraiva, 2011.

ARGENTINA. Corte Suprema de Justicia. Mazzeo, Julio Lilo y otros s/ rec. de casación e inconstitucionalidad. Sentença de 13 de julho de 2007. Disponível em: < 
http://www.csjn.gov.ar/jurisp/jsp/fallos.do?usecase=mostrarDocumento\&falloId=1951>. Último acesso: 04 de abril de 2016.

BINDER, Christina. The prohibition of amnesties by the inter-american court of human rights. German Law Jornal, v 12, n. 5, 2010, p. 1203-1230. Disponível em: <http://www.corteidh.or.cr/tablas/r26381.pdf>. Último acesso em: 08 junho 2016.

BRASIL. Código de Processo Civil.Brasília, DF, 2015.

BRASIL. Constituição da República Federativa do Brasil de 1988. Brasília, DF, 1988.

BRASIL.Decreto $n^{\circ}$ 6.949, de 25 de agosto de 2009. Promulga a Convenção Internacional sobre os Direitos das Pessoas com Deficiência e seu Protocolo Facultativo, assinados em Nova York, em 30 de março de 2007. Brasília,DF, 26 agosto 2009.

BRASIL. Supremo Tribunal de Federal. Habeas Corpus 72131-RJ. Relator: Ministro Marco Aurélio, Plenário, Brasília, DF, DJ 23 nov..1995.

- Supremo Tribunal de Federal. Recurso em Habeas Corpus 79785-RJ, Relator Sepúlveda Pertence, Plenário, DJ 19 set.2003.

BRASIL. Supremo Tribunal de Federal. Recurso Extraordinário 466343-1 SP. Relator: Ministro César Peluso, Plenário, Brasília, DF, DJ 03 dez. 2008. Disponível em: < http://redir.stf.jus.br/paginadorpub/paginador.jsp?docTP=AC\&docID=595444>. Último acesso: 30 agosto 2016.

BRASIL. Supremo Tribunal Federal. Recurso Extraordinário n. 80.004-SE. Relator: Ministro Xavier de Albuquerque, Plenário, Brasília, DF, DJ, 1 de jun. de 1977. Disponível em: < http://redir.stf.jus.br/paginadorpub/paginador.jsp?docTP=AC\&docID=175365>. Último acesso: 30 agosto 2016.

. Supremo Tribunal de Federal. Recurso Extraordinário 466343-1 SP, Relator César Peluso, Voto do Min. Gilmar Mendes, DJ 05 jun. 2009.

BRASIL. Tribunal de Justiça do Rio de Janeiro. Processo $n^{o}$ 0013156-07.2015.8.19.0008. $2^{\mathrm{a}}$ Vara Criminal da Comarca de Beldford Roxo, Beldford Roxo, RJ, DJ 04.07.2016. Disponível em: < http://emporiododireito.com.br/juiz-do-tjrj-faz-controle-de-convencionalidade-do-crimede-desacato/>. Último acesso: 05 agosto 2016.

. Tribunal de Justiça de Santa Catarina. Ação Penal $n^{\circ}$ 0067370-64.2012.8.24.0023, $4^{\mathrm{a}}$ Vara Criminal da Comarca de Florianópolis, Florianópolis, SC, DJ 17 mar. 2015.

Tribunal de Justiça do Paraná. Habeas Corpus $N^{o} 1.358 .323-2,3^{\mathrm{a}}$ Vara Criminal do Foro Central da Comarca da Região Metropolitana de Curitiba, Curitiba, SC, DJ 23 abril 2015. Disponível em: https://www.tjpr.jus.br/documents/18319/5218101/Processo_N\%C2\%BA_1358323-2__HC_Crime.pdf>. Última visita: 04 de abril de 2016.

CARVAlHO, Alexander Perazo Nunes de. Convencionalização do direito civil: a aplicação dos tratados e convenções internacionais no âmbito das relações privadas. Revista de Direito Internacional, v. $12, \quad$ n. 2, 2015, p. 342-354. Disponível em: < 
http://www.publicacoesacademicas.uniceub.br/index.php/rdi/article/view/3756/pdf>. Último acesso: 30 agosto 2016.

CORTE INTERAMERICANA DE DIREITOS HUMANOS. Advisory Opinion OC-21/14. Opinião Consultiva de 19 agosto 2014.

- Caso Almonacid Arellano y otros Vs. Chile. Fondo, Reparaciones y Costas. Sentença de 26 de setembro de 2006, série c, nº 154.

- Caso Barrios Altos Vs. Perú. Sentença de 14 de março de 2001.

. Caso "La Última Tentación de Cristo" (Olmedo Bustos y otros) Vs. Chile. Fondo, Reparaciones y Costas. Sentença de 5 de fevereiro de 2001, série c, $\mathrm{n}^{\mathbf{0}} 73$.

- Caso La Cantuta Vs. Perú. Fondo, Reparaciones y Costas. Sentença de 29 de nov. 2006.

. Caso Gelman vs. Uruguay. Fondo, Reparaciones. Sentença de 24 de fevereiro de 2011.

de novembro de 2010. série c, $\mathrm{n}^{\mathrm{o}} 101$.

. Caso Myrna Mack Chang Vs. Guatemala. Sentença de 25 de novembro de 2003,

CORTE INTERAMERICANA DE DIREITOS HUMANOS. Caso Palamara Iribarne vs. Chile. Fondo Reparaciones y Costas. Sentença de 22 de novembro de 2005.

. Caso Tibi Vs. Ecuador. Sentença de 07 de setembro de 2004.

Caso Trabajadores Cesados del Congreso (Aguado Alfaro y otros) Vs. Perú. Fondo, Reparaciones y Costas. Sentença de 24 de novembro de 2006, série c, n⿳0 158.

Supervisão de Cumprimento de Sentença Caso Gomes Lund e Outros ("Guerrilha do Araguaia”) vs. Brasil. Resolução de 17 de outubro de 2014.

DULITZKY, Ariel E. An Inter-American Constitutional Court? The invention of the Conventionality Control by the Inter-American Court of Human Rights. Texas International Law Journal, vol. 50, 2015, p. 45-93. Disponível em: <http://www.conseil-constitutionnel.fr/conseilconstitutionnel/root/bank/download/7454DCa7454dc.pdf>. Último acesso: 19 set. 2016.

FERNANDES, Bernardo Gonçalves. Curso de Direito Constitucional, 6 ed. Salvador: Juspodium, 2014.

FRANÇA. Conselho Constitucional Francês. Decision 74-54 DC, Voluntary Interruption of Pregnancy Act. Decisão de 15 jan. 1975. Disponível em: <http://www.conseilconstitutionnel.fr/conseil-constitutionnel/root/bank/download/7454DCa7454dc.pdf>. Último acesso: 30 agosto 2016.

. Constituição da Quinta República de 1958. Disponível em: <http://www.conseilconstitutionnel.fr/conseil-constitutionnel/root/bank_mm/portugais/constitution_portugais.pdf $>$. Último acesso: 30 agosto 2016.

LARRIEUX, Jorge T. Caso Gelman vs. Uruguay. Justicia transicional, Corte Interamericana de Derechos Humanos y el control de convencionalidad. Anuário de Derecho Constitucional Latinoamericano, ano XIX, 2013, p. 589-606. Disponível em: < http://www.juridicas.unam.mx/publica/librev/rev/dconstla/cont/2013/pr/pr33.pdf>. Último acesso: 08 de junho de 2016. 
MACEDO, Paulo. Comentários ao artigo 27. In SALIBA, Aziz Tuffi (org.). Direito dos tratados: comentários à Convenção de Viena sobre o direito dos tratados (1969). Belo Horizonte: Arraes Editores, 2011, p.191-197.

MAC-GREGOR ,Eduardo Ferrer, Conventionality Control: The New Doctrine of the InterAmerican Court of Human Rights, American Journal of International Law Unbound, 93, 2015, p.93-99. Disponível em: <https://www.asil.org/sites/default/files/Ferrer\%20MacGregor\%2C\%20Conventionality\%20Controlv3.pdf>. Último acesso: 30 agosto 2016. Interpretación conforme y control difuso de convencionalidad el nuevo paradigma para el juez mexicano. In MARINONI, Luiz Guilherme; MAZZUOLI, Valerio de Oliveira (Org.). Controle de Convencionalidade: um panorama latino-americano: Brasil, Argentina, Chile, México, Peru, Uruguai. Brasília, DF: Gazeta Jurídica, 2013, p.547-596.

MAC-GREGOR, Eduardo Ferrer. DOMÍNGUEZ, Pablo González. Death Penalty, Amnesty Laws, and Forced Disappearances: Three Main Topics of the InterAmerican Corpus Juris in Criminal Law. Notre Dame Journal of International \& Comparative Law: Vol. 5: Iss. 1, Article 4, p.63-113. Disponível em: <http://scholarship.law.nd.edu/cgi/viewcontent.cgi?article=1029\&context=ndjicl>. Último acesso: 08 junho 2016.

MARINONI, Luiz Guilherme et al.Novo Código de Processo Civil Comentado. São Paulo: Revista dos Tribunais, 2015.

MARINONI, Luiz Guilherme; MITIDIERO, Daniel; SARLET, Ingo Wolfgang. Curso de Direito Constitucional. São Paulo: Editora Revista dos Tribunais, 2012.

MARTINS, Leonardo; MOREIRA, Thiago Oliveira. Constitucionalidade e Convencionalidade de Atos do Poder Público: concorrência ou hierarquia? Um contributo em face da situação jurídico constitucional brasileira. Anuario de Derecho Constitucional Latinoamericano, AÑO XVII, Montevideo, 2011, pp. 463-483.

MAZZUOLI, Valerio de Oliveira. O controle jurisdicional da convencionalidade das leis, 3. ed. ver., atual. e ampl. São Paulo: Editora Revista dos Tribunais, 2013.

. Teoria Geral do Controle de Convencionalidade no Direito Brasileiro. Revista da Associação dos Juízes do Rio Grande do Sul, ano XXXVI, no 113, 2009, p. 333-370.

. Teoria Geral do Controle de Convencionalidade no Direito Brasileiro. In In

MARINONI, Luiz Guilherme; MAZZUOLI, Valerio de Oliveira (Org.). Controle de Convencionalidade: um panorama latino-americano: Brasil, Argentina, Chile, México, Peru, Uruguai. Brasília, DF: Gazeta Jurídica, 2013, p.3-56.

MÉXICO. Constitución Política de los Estados Unidos Mexicanos de 1917. Disponível em: <http://www.ordenjuridico.gob.mx/Constitucion/cn16.pdf>. Último acesso: 04 de abril de 2016.

NEGISHI, Yota. The Pro Homine Principle's role in regulating the relationship between Conventionality Control and Constitutionality Control. Max Plank Institute for Comparative Public Law and International Law (MPIL) Research Paper Series, n.13, 2016, p. 1-27. Disponível em: <http://papers.ssrn.com/sol3/papers.cfm?abstract_id=2791008>. Último acesso: 30 agosto 2016. 
ORGANIZAÇÃO DAS NAÇÕES UNIDAS. Convenção de Viena sobre o Direito dos Tratados. 1969.

Estatuto da Corte Internacional de Justiça. 1945. Disponível em:< http://www.direitoshumanos.usp.br/index.php/Corte-Internacional-de-Justi\%C3\% A7a/estatutoda-corte-internacional-de-justica.html>. Último acesso: 04 de abril de 2016.

ORGANIZAÇÃO DAS NAÇÕES UNIDAS. Convenção de Viena sobre o Direito dos Tratados. Viena, 23 maio $1969 . \quad$ Disponível em: https://treaties.un.org/doc/publication/unts/volume\%201155/volume-1155-i-18232-english.pdf $>$. Último acesso: 30 agosto 2016.

ORGANIZAÇÃO DOS ESTADOS AMERICANOS. Convenção Americana sobre Direitos Humanos (Pacto de San José da Costa Rica). San José, 1969. Disponível em: < https://www.cidh.oas.org/basicos/portugues/c.convencao_americana.htm>. Último acesso: 30 agosto 2016.

RAMOS, André de Carvalho. Pluralidade das ordens jurídicas: a relação do direito brasileiro com o direito internacional.Curitiba: Juruá, 2012.

SÁGUES, Nestor Pedro. El "control de convencionlad" em el sistema interamericano, y sus anticipos em el âmbito de los derechos econômico-sociales. Concordancias y diferencias com el sistema europeo. Instituto de Investigaciones Juridicas, 2012, p.381-417. Disponível em: <http://www.ijf.cjf.gob.mx/cursosesp/2012/derhumancontrolconvencionalidad/Nestor\%20Sagues .pdf>. Último acesso em: 08 junho 2016. 